DOI: $10.14746 /$ por.2018.1.19

\title{
ПОЛЯКИ В ПРИЕНИСЕЙСКОЙ СИБИРИ В ПЕРВЫЕ ГОДЫ ПОСЛЕ РЕВОЛЮЦИИ 1917 Г.
}

\author{
ВЛАДИМИР ГРИГОРЬЕВИч ДАЦЫШЕН ${ }^{1}$ \\ (Сибирский федеральный университет; \\ Красноярский государственный педагогический университет)
}

Keywords: Poles, Central Siberia, Yenisei Province, Krasnoyarsk, 5th Polish Division, prisoners of war, repatriation

Słowa kluczowe: Polacy, Syberia Środkowa, Gubernia Jenisejska, Krasnojarsk, V Dywizja Strzelców Polskich, jeńcy wojenni, repatriacja

\begin{abstract}
Vladimir G. Datsyshen, POLES IN THE YENISEI SIBERIA REGION DURING THE FIRST YEARS AFTER THE REVOLUTION OF 1917. "PORÓWNANIA" 1 (22), 2018. Vol. XXII, P. 327-341. ISSN 1733-165X. The article is devoted to the history of Poles in Central Siberia. At the beginning of the 20th century there were exiles and their descendants, as well as migrants and civil servants in the Yenisey province. During the First World War thousands of refugees and Polish prisoners of war were housed in this region. They took part in the events of the civil war on both sides. Krasnoyarsk was at the center of the "Polish question” in Siberia in 1920 as the 5th Polish division capitulated there. The Bolsheviks tried to rely on foreigners, but most Poles linked their future with their national state. The repatriation events have become a complex and tragic page of the history of the Polish diaspora as more than 10 thousand Poles lived in the Yenisei Siberia Region.
\end{abstract}

Abstrakt: Vladimir G. Datsyshen, POLACY W SYBERII NADJENISEJSKIEJ W PIERWSZYCH LATACH PO REWOLUCJI 1917 R. „PORÓWNANIA” 1 (22), 2018. T. XXII, S. 327-341. ISSN 1733-165X. Artykuł poświęcony został historii Polaków w Syberii Środkowej w trudnym i burzliwym okresie pierwszych lat po Rewolucji w Rosji w 1917 roku. Już na początku XX wieku Gubernię Jenisejską zamieszkiwało dużo Polaków - zesłańcy i ich potomkowie, przesiedleńcy, urzędnicy państwowi. Podczas I wojny światowej w tym regionie osiedlono tysiące uciekinierów i polskich jeńców wojennych, którzy aktywnie uczestniczyli w wojnie domowej po obu zwalcza-

1 E-mail: dazishen@mail.ru 
jących się stronach. Legion polski, jak też rosyjscy Polacy, w dużej mierze określili miejsce i rolę Krasnojarska w wydarzeniach związanych z kapitulacją Armii Kołczakowskiej. Syberia Nadjenisejska znalazła się w centrum „polskiej kwestii” w Syberii w 1920 roku, kiedy właśnie tam nie tylko skapitulował, ale i na długi czas był rozmieszczony skład piątej polskiej dywizji. Bolszewicy w Krasnojarsku próbowali polegać na Polakach w osiąganiu swych celów politycznych. Jednak większość Polaków w Syberii wiązała swoją przyszłość z narodowym państwem polskim i wydarzenia związane z repatriacją stały się trudną i tragiczną stroną historii polskiej diaspory. W końcu zaledwie jednej trzeciej mieszkających na Syberii Środkowej Polaków udało się wyjechać do Polski w latach 1921-1922, podczas gdy ponad 10000 osób zostało w tym regionie.

В начале $\mathrm{XX}$ в. поляки составляли заметную часть населения всей Сибири, в том числе и Приенисейского края. Польская община Сибири сформировалась в основном за счет ссыльных из входившей в состав Российской империи Польши, а также переселенцев и прибывших на службу лиц польской национальности. По переписи 1897 г. в Енисейской губернии было зафиксировано почти 6 тыс. Поляков (Дроздов 485) . К началу Первой мировой войны в Енисейской губернии проживало более 15 тыс католиков (Быконя 181), в подавляющем большинстве это были поляки. В регионе проживали не только поляки-католики, но и поляки-лютеране (мазуры).

Во время Первой мировой войны число поляков в Енисейской губернии значительно выросло. Польская община пополнилась беженцами и переселенцами из западных районов Российской империи. В Сибири были размещены военнопленные поляки из Германской и Австро-Венгерской армий.

Первая Мировая война дала толчок новому этапу развития польской общины в Сибири. Изменения были обусловлены не только резким ростом числа поляков, но и постепенным изменением общественно-политической ситуации в стране. В частности, накануне революции 1917 г. в армии Российской империи впервые были сформированы национальные польские части. В специальной публикации по проблеме «национально-территориального комплектования частей пехоты» говорилось: «во время настоящей войны были сформированы польские и латышские части, но при их сформировании был принято во внимание лишь принцип национальности... независимо от места его рождения или жительства»². Таким образом, сибирские поляки получили право и опыт службы в национальных польских воинских частях.

В силу комплекса причин история поляков в Сибири в годы революции и гражданской войны слабо отражена в мемуарной литературе ее участников. Даже известный ученый и общественный деятель А.Ф. Оссендовский, ставший всемирно известным благодаря своей популярной книге о гражданской войне в Сибири, не оставил ни строчки воспоминаний о службе в Сибири в 1918-1919 гг. В автобиографиях, как и в биографической литературе, слабо

2 Разведчик. 1917. 30 октября. 
освещена деятельность известных красноярских поляков, таких как архитектор В. А. Соколовский, ботаник А. Л. Яворский и др., в годы гражданской войны.

В советской историографии история поляков в Сибири во время революции, гражданской войны и первые годы советской власти оставалась слабо изученной. В начале 1990-х гг. один из самых авторитетных сибирских полонистов Б. С. Шестакович отметил: «Приходится констатировать, что наряду с контингентом польских экономических мигрантов в Сибирь начала XX в., последующее расширение польской диаспоры с началом мировой войны и дальнейшие ее метаморфозы, вызванные драматичными процессами революционных ломок, гражданской войны и интервенции остаются почти целиком «белыми пятнами» в отечественной историографии. До недавнего времени подход к данной эпохе оставался односторонне избирательным по сугубо идеологической направленности. Все внимание советских исследователей сводилось лишь к полякам-интернационалистам... При этом совершенно выпал из их поля зрения процесс воплощения в эти годы в Сибири национальной польской идеи (в частности, функционирование здесь так называемой 5-й польской Сибирской дивизии)» (Шостакович 144-145).

В последние годы история поляков в Сибири после революции 1917 г. активно изучается, как сибирскими, так и польскими учеными. Однако до сих пор не восстановлена полностью историческая картина событий тех лет, не проанализирован весь комплекс проблем, связанный с развитием польского движения на востоке России. Особенную актуальность сохраняет история поляков в Центральной Сибири, имеющей определенную специфику региона, и при этом остающегося наименее изученным. Целью нашей статьи является выявление проблем польского населения и восстановление исторической картины развития польской общины в Приенисейской Сибири в 1917 - 1924 гг.

В 1917 г. в различных городах востока России возникли польские организации. Не стала исключением здесь и столица Приенисейской Сибири - Красноярск. 18 мая 1917 г. был принят устав «Союза польских беженцев в Красноярске» (Минина 11). Красноярск в части общей политической атмосферы имел значительные особенности, здесь преобладали пробольшевистские настроения и гораздо слабее были развиты буржуазно-националистические движения, чем в других сибирских городах. Исследователь И. В. Нам пишет: «Польский митинг в Красноярске (300 человек), состоявшийся 4 апреля 1917 г., напротив, закончился полной победой большевиков» (Нам 51).

В 1917 г. Енисейская губерния не была в центре национальных движений в Сибири, хотя представители разных национальных общин фиксировались в различных событиях в регионе. Исследователь А. П. Шекшеев, например, приводит случай: «вечером 7 декабря группа поляков во главе с военнопленным австрийцем, в масках и вооруженная наганами, под видом милиции на- 
пала на номера в красноярском «Эрмитаже», где изъяла у приехавшего из Москвы часовщика серебряный портсигар, золотую брошь и цепочку из американского золота» (Шекшеев 87).

Выходцы из Польши были активными участниками революционных событий в Красноярске в 1917-1918 гг. Директор Красноярского железнодорожного технического училища статский советник Александр Феликсович Парадовский (Порадовский) весной 1918 г. стал большевистским комиссаром железной дороги и был расстрелян белочехами. Уроженец Польши Виктор Самуилович Маерчак, сосланный в Енисейскую губернию по приговору Варшавского суда, был одним из лидеров местных большевиков, в 1918 г. был арестован белочехами и позднее расстрелян.

Но в период гражданской войны местные поляки активно вступали в антисоветсткие отряды ополчения, и дружины самообороны защищая свои города и села от красных партизан. Например, за это в 1920-х гг. подверглись репрессиям несколько поляков в Минусинске. О поляках во время Гражданской войны в Енисейской губернии можно судить по «спискам амнистированных заключенных» польских подданных Минусинского дома лишения свободы. Были среди поляков обвиняемые: «в скрытии офицерского звания и неисполнении приказаний», «в с даче белой банде с отрядом», «в выдаче и избиении красных партизан и антисоветской агитации», «в контрреволюционном заговоре, злоумышленном побеге из Красной армии», «в преступлении по должности» ${ }^{3}$.

Некоторые поляки бежали в Белую Сибирь из Советской России с целью продолжения борьбы с большевизмом. Например, в марте 1918 г. приехал из Петрограда в Томск известный общественный деятель и публицист А. Ф. Оссендовский. Он был в числе организаторов и идеологов свержения большевиков в мае 1918 г. в Томске. Поляк А. Ф. Оссендовский направил свои силы на развитие «автономной» Сибири, например, 18 августа 1918 г. он выступил на Торгово-промышленном съезде Приенисейского края. В Правительстве Колчака работал еще один сибирский поляк - профессор биологии В. Ч. Дорогостайский. Оставался верным российскому правительству кавалер ордена Св. Георгия Бронислав Михайлович Зиневич (католик). После увольнения из армии в конце 1917 г. он жил в Красноярске, а в июне 1918 г. был назначен командиром 1-го Енисейского стрелкового полка.

Осенью 1918 г. на территории Сибири шел процесс консолидации поляков на основе идеи возрождения польского государства. Процесс этот был тесно связан с созданием польских воинских частей в Сибири, которые должны были придерживаться нейтралитета в отношении событий гражданской войны в России. Одной из самых активных польских организаций в то время

3 Архив города Минусинска. Ф. Р-34. Оп. 1. Д. 4. Л. 81-82. 
был Польский военный союз в Красноярске. Местный сборный пункт во главе с поручиком Владиславом Земба в начале 1919 г. подчинялся Новониколаевскому сборному пункту. В Красноярске была создана общественная организация «Друг польского воина».

Польское национальное движение в Центральной Сибири не ограничивалось военными организациями или стремлением к возрождению польского государства. В уставе учрежденного в конце 1918 г. в Канске «Польского культурно-просветительного общества «Огниво»» говорилось, что «Целью... являются: культурно-просветительная деятельность в Канске и его уездах, идейное объединение рассеянных на чужбине поляков, крепление в них начал польской самобытности и чувства братства всем славянским народам...», а членами общества могли быть «русские подданные польского происхождения без различия пола и вероисповедания» (Минина 17). В Красноярске и Минусинске были организованы польские скаутские дружины.

К лету 1919 г. в Сибири была сформирована 5-я Польская дивизия численностью более 10 тыс. человек. Большинство годных к воинской службе поляков, находившихся в Центральной Сибири и желавших вернуться на родину, независимо от политических предпочтений, вступили в эту дивизию. Красноярские большевики так характеризовали польских легионеров: «Низкий культурный уровень галицийских и познанских поляков в значительной мере обеспечил успех злонамеренной агитации, которая велась среди них агентами мирового империализма в целях создания в Сибири из бывших военнопленных передовых отрядов европейской черной рати. Кроме этого малосознательного элемента в составе легионеров было значительное количество искренних защитников капиталистического строя, представителей крупной и мелкой буржуазии, и совсем ничтожное количество поляков, преимущественно, выходцев из б. Царства Польского, которые скрылись в легионах от преследования Колчака... на почве недовольства навязанной легионерам ролью защитникам империализма, дезертирство стало заурядным явлением в польской армии, несмотря на то, что, в случае поимки, беглецы беспощадно расстреливались» 4 .

Польская дивизия формально не участвовала в гражданской войне, но, занимаясь охраной железной дороги, постоянно вступала в бои с красными партизанами. В конце 1919 г. польская дивизия шла в арьергарде колчаковских и чехословацких войск, прикрывая их отступление. Красноярск 5-я дивизия все же прошла, не вступая в противостояние с уже поставившими город под свой контроль большевиками, но лишь на 100 км далее на восток. Если в Красноярске мост через Енисей поляки смогли сохранить, его защищал бронепоезд «Краков», то перед Тайшетом чехословаки успели взорвать мосты.

4 Разведчик. 1917. 30 октября. 
Уже в Красноярске польские легионеры еще до капитуляции вполне мирно уживались с красноармейцами. Такая ситуация, несомненно, была вызвана тем, что 5-я польская дивизия пришла в Красноярск после того, как командующий войсками Енисейского района и начальник Красноярского гарнизона российский генерал поляк Б. М. Зиневич возглавил восстание против Колчака. Поляки находились в Красноярске в то время когда красные партизаны входили в город, а бывший колчаковский генерал-поляк оборонял столицу Енисейской губернии от Белой армии. Генерал Зиневич не пропустил следовавшего за 5-й польской дивизией русскую Белую армию, которая и обошла Красноярск и район станции Клюквенной стороной.

Как пишет польский исследователь: «Под станцией Клюквенная польские эшелоны окончательно остановились. После военного совета командование решилось приступить к переговорам с большевиками. 10 января 1920 г., согласно условиям капитуляции, польские части сложили оружие. Часть солдат не согласилась с капитуляцией и пробилась на восток» (Висьневский 248). Красноярская газета сообщала: «Между станциями Балай и Красноярск стоит 33 разоруженных польских эшелона. По получению топлива эшелоны будут немедленно переброшены в Красноярск, на западный берег» 5 .

Согласно официальным данным красноярских большевиков, «в Красноярске и его окрестностях» К началу весны 1920 г. находилось около 12000 чел. «польских легионеров б. колчаковской армии» ${ }^{6}$ Исследователь Л. К. Островский пишет: «По сведениям бывших пленных поляков, ни один из пунктов условий капитуляции не был большевиками выполнен. Офицеры, солдаты и их семьи были ограблены. Женщины и дети оказались на улицах Красноярска фактически без средств к существованию. Правда, часть солдат, воспользовавшись неразберихой... сумела скрыться в населенных пунктах Томской, Енисейской и Иркутской губерний» (Островский 2008: 91).

Сдавшиеся Красной Армии поляки были интересны новой власти, и как высококвалифицированные специалисты для решения неотложных хозяйственных задач, и как потенциальные союзники и единомышленники. В газете «Красноярский рабочий» вскоре появилась заметка «По нашему краю. (На ст. Клюквенная)», в которой говорилось: «Здесь осталась Польская жел. дор. рота, которая также привлекается к работам по восстановлению паспорта. Среди поляков имеются горные инженеры, которых не бесполезно было бы использовать для разработки угольных копей, уже функционирующих на ст. Балай. Организовалась и работает ячейка коммунистической партии» ${ }^{7}$.

5 Красноярский рабочий. 1920. 18 января.

6 Красноярский рабочий. 1920. 10 марта.

7 Красноярский рабочий. 1920. 5 марта. 
В 1920-1921 гг. поляки 5-й дивизии находились в лагерях для военнопленных в городах Центральной Сибири. Основная масса военнопленных поляков содержалась в Красноярске. Как указывают историки: «Всего в Красноярском лагере находилось примерно 8 тыс. пленных поляков» (Островский 2008: 91). В 1921 г. в лагере Канского гарнизона содержался 20-ти летний поляк из 5-й Польской дивизии Михаил Казимирович Врубель. Сибирская исследовательница Р. Оплаканская установила биографические данные 418 военнопленных поляков, проживавших в Минусинском уезде, в том числе 236 - из Австро-Венгрии, 148 - России, 33 - Германии и 1 из Сербии. Большая часть пленных поляков там была направлена в рамках всеобщей трудовой повинности на угледобывающие предприятия.

Польский легион фактически помог большевикам отстоять Красноярск от Белой армии в начале января 1920 г., не допустил взрыва моста через Енисей, и после этого без боя капитулировал. Это обусловило особое отношение к польским военнопленным. Исследователи отмечают: «Пленные поляки Минусинского уезда значились как гражданские лица, т. е. не подлежали судебному преследованию как активные противники Советской власти» (Оплаканская 2014: 96). Вообще, местные большевистские газеты в публикациях о польских легионерах и о поляках вообще весной 1920 г. не высказывали негативных оценок и характеристик.

Поляки, как и другие группы населения не могли избежать массовых репрессий со стороны новых властей. Выявленные среди поляков «враги Советской власти», как из числа бывших польских офицеров, так и активистов антисоветского движения в годы Гражданской войны в регионе, подвергались суду и арестам. Например, А. И. Язвинский был арестован за вербовку добровольцев в «польские легионы для борьбы с Советской властью при Колчаковском правительстве» (Оплаканская 2014: 97).

В начале ноября 1921 г. уполномоченный польской делегации направил в российско-украинскую делегацию список военнопленных (всего 31 человек), которые находились в красноярской тюрьме. (Оплаканская 2015: 123). Показательна судьба бывшего генерала Б. М. Зиневича, сдавшего Красноярск большевикам. Генерал несколько раз заявлял, что он польский подданный, но не имел документов по этому поводу. Он несколько раз арестовывался и отпускался, принимался на службу в Красную Армию и увольнялся. В конце концов, в 1922 г. Б. М. Зиневич был «заключен в концлагерь до обмена с Польшей», где и погиб.

В ситуации массовой репатриации поляков, советские органы власти проявляли повышенное внимание к этой группе населения. Значительная часть поляков попала под репрессии. В приказе Минусинского исполкома по поводу поляков говорилось: «впредь незарегистрировавшиеся, как явно укрывающиеся, должны были заключены в концентрационный лагерь» (Оплаканская 
2014: 97). В «протоколе заседания коллегии управления Енгубисполкома» от 10 марта 1922 г. говорилось: «Концентрацию военнопленных поляков продолжать производить при колонии лит. «А». Ввиду достигнутого соглашения с представителем польской миссии и в связи с переходом лагеря на самоснабжение довольствие выдавать только тем из концентрированных поляков, которые по распоряжению администрации лагеря будут ходить на работы, и инвалидам. Отказывающимся от работы паек не выдавать, предоставив им право поступления на службу и самостоятельного заработка себе пайка, с обязательством явки в лагерь для регистрации в срок, установленный администрацией лагеря... Штат концентрационного польского лагеря утвердить в составе коменданта тов. Надржецкого и помощника его тов. Хлебовского» (Минина 48-49).

Установившаяся в 1920 г. в Приенисейской Сибири власть большевиков сразу уделила особое внимания вопросам работы с поляками. Кроме 12 тыс. бывших польских легионеров, в регионе находились многочисленные военнопленные и беженцы. В статистической сводке по Енисейской губернии на 1 марта 1921 г. в числе зарегистрированных военнопленных в Енисейской губернии было 232 австрийских поляка, 37 германских поляка (Минина 29). В числе беженцев, общей численностью 6483 чел., было 579 поляков (Минина 29). Но в Центральной Сибири имелось многочисленное местное польское население. По данным «Всероссийской переписи 1920 г.» в Енисейской губернии проживало 6765 мужчин и 5058 женщин польской национальности (Минина 47).

После установления советской власти вопросами развития польской общины в Центральной Сибири занимался Подъотдел национальных меньшинств Енисейского губернского комитета РКП(б). В Енгубкоме РКП(б) было создано 7 национальных секций. Созданная в феврале 1920 г. польская секция отвечала за вторую (после татарской) по численности (около 30 тыс. чел) национальную общину.

Газета «Красноярский рабочий» в марте 1920 г. сообщала: «В начале февраля месяца текущего года в Красноярске сорганизовалась Польская секция Р.К.П., выделившая из своей среды временный комитет, в составе: председателя - т. Рыковского, членов - т. т. Лесневского, Воевского, Матушевской и Брутковского и секретаря т. Познанского. Означенный Комитет поставил своей основной задачей организацию в пределах Енисейской губ. сильной польской коммунистической партии и установление самой тесной связи с другими польскими секциями... Свою организационную деятельность Комитет ведет в полном контакте с местным комитетом Р.К.П. И его интернациональной секцией. Для координирования своих действий с Московским Комиссариатом по польским делам во главе которого стоит известный коммунист т. Мархельский. Комитет отправил в Москву срочную телеграмму, на которую 
со дня на день ожидает ответа» ${ }^{8}$. Первоначально функционировала только губернская секция, работавшая в Красноярске и Красноярском уезде, в других уездах Енисейской губернии таковые секции не были открыты. Среди руководителей польской секции историки называют Врублевского. В конце 1921 г. секретарем польской секции был В. П. Фронк. Среди членов секции были И. Шлягор, М. Ф. Матюшинский, Кончевский и другие.

Говоря о первом опыте агитационно-пропагандистской работы среди поляков, красноярские большевики в марте 1920 г. утверждали: «выпавшая на долю Комитета Польской секции задача оказалась не из легких: первые зерна коммунизма упали на мало подготовленную почву. При этом агитационная деятельность Комитета сильно осложнилась отсутствием партийной литературы на польском языке и плохим знанием легионерами русского языка. Ограничив свою деятельность на первых порах устройством митингов для поляков и энергичной устной пропагандой, Комитет принял все, зависевшие от него меры для издания на польском языке коммунистический газеты, но безуспешно, вследствие недостатка бумаги. Все что удалось сделать в этом направлении Комитету, свелось к выпуску прокламации на польском языке к польским рабочим и крестьянам с горячим призывом осознать свои классовые задачи, стать под знамя III Коммунистического Интернационала. Упорная работа Комитета уже дала значительные результаты: среди легионеров организуются коммунистические ячейки, классовое самосознание рабочих и крестьян начинает выявляться, замечается массовое стремление их в Красную Армию»9.

Именно военнопленные 5-й Польской дивизии виделись большевикам как наиболее благодатная среда для коммунистической пропаганды. В отношении местного польского населения в газете отмечалось: «Что касается деятельности Комитета среди поляков, не принадлежащих к составу легионеров, то таковая тормозится тем обстоятельством, что большинство их приобрело в Красноярске оседлость, обзавелись недвижимостями и прониклись мелко-буржуазными взглядами» ${ }^{10}$.

23 февраля 1921 г. в Красноярске на польском собрании присутствовал инструктор ЦК РКП(б) член польского бюро при ЦК РКП(б) Форнальский. На собрании принята резолюция: «Собрание членов и кандидатов партии г. Красноярска и рабочей бригады из бывших легионеров-поляков 5-й дивизии... постановили: Мы коммунисты-поляки в революционной России отдаем всю свою силу молодой пролетарской республике. Шлем товарищам в Польшу свой коммунистический привет и полную солидарность» (Улейская 72). На 1 октября 1921 г. Енгубкоме РКП(б) было 6 секций - латышская, татарская,

8 Красноярский рабочий. 1920. 10 марта.

9 Красноярский рабочий. 1920. 10 марта.

10 Красноярский рабочий. 1920. 10 марта. 
корейская, польская, эстонская, немецкая. В 1922 г. при Губкоме остались лишь латышская и эстонская национальные секции, остальные были упразднены.

На первом этапе национально-государственного строительства в Сибири большевики столкнулись с объективными противоречиями, вызванными как наследием имперской истории России, так и реалиями революционной эпохи. В «Отчете Енисейского Губернского Экономического Совещания Совету Труда и Обороны и Сибирскому Областному Экономическому Совещанию с 1-го Октября 1921 г. по 1-е Мая 1922 г.» говорилось: «Вопрос о работе среди национальных меньшинств губернии вызвал серьезные разногласия о дальнейшем ведении ее. В то время, как одни высказывались за ведение ее в полном объеме, другие, наоборот, находили целесообразным совершенно ликвидировать ее, как ненужную, ссылаясь на то, что национальные особенности в условиях Енисейской губернии успели уже стереться и большинство национальностей в значительной степени обрусело. Восторжествовала, однако, первая точка зрения, но работу специальным аппаратом постановлено было вести в губернском масштабе лишь среди татарской, эстонской, польской и латышской национальностей. Как насчитывающих в своем составе не менее 5000 человек, и в уездном среди хакасской национальности и немцев колонистов Минусинского уезда; среди же других национальностей работа должна вестись общесоветским аппаратом. В связи с этим в феврале с. г. был реорганизован весь аппарат по делам национальностей: все существующие секции были закрыты, равно как и Отдел Губнаца... вместо них образовалась коллегия из Заведывающих п/отделами национальных меньшинств при Губкоме Р.К.П. и Губуполномоченного при Губисполкоме. В самое последнее время в целях большей устойчивости организационного аппарата, решено назначить в качестве нештатных должностей губернских, уездных и районных представителей указанных выше национальностей эстонской, татарской, латышкой и польской, а также и чувашской» (Отчет 313). Таким образом, после окончательного установления советской власти в Центральной Сибири большевики и местная власть признавали польскую общину в качестве одной из самых многочисленных и важных в этно-национальной структуре Енисейской губернии.

В начале 1920-х гг. сложным и противоречивым был вопрос об организации польских национальных школ или введения обучения поляков на польском языке. Исследователи указывают, что в 1921-1922 г. в Енисейской губернии существовало несколько польских школ - в Канске, в селах Конок, Шелехово и других (Улейская 73). Официальные документы указывают, что в отличие от других нацменьшинств, в 1923-24 уч. году в губернии не было ни одной польской школы и ни одного польского учителя. На следующий год одна школа была открыта (Минина 96-97). В ней училось 36 детей и работала одна русская учительница. 
Положение поляков в Сибири осложнилось из-за неудач, постигших Красную Армию в Советско-польской войне. Первоначально большевики надеялись на поддержку идей социалистической революции в Польше. В марте 1920 г. красноярские большевики, сообщая о создании местной Польской секции РКП(б), писали: «Для обострения в Польше классовой борьбы, для ускорения взрыва рабоче-крестьянской революции, почва для которой в общем достаточно подготовлена, Комитет считает необходимым создание кадров опытных партийных работников. Влившись в качестве агитаторов в рабоче-крестьянские массы, они, несомненно, в короткий срок создали бы мощную коммунистическую организацию, которая обеспечила бы успех пролетарской революции в Польше» ${ }^{11}$.

В «Приказе № 82 Ачинской Уездной Чрезвычайной Комиссии по борьбе с контр-революцией, спекуляцией и преступлениями по должности от 19 июля 1920 г.» за подписью председателя уездного ЧК Фридмана говорилось: «Всем гражданам польской национальности, проживающим в г. Ачинске, обоего пола, от 18 летнего возраста, вменяется в обязанность в трёхдневный срок зарегистрироваться в Комендантском отделе Учека с 4-х часов дня до 9-ти часов вечера: первым днём регистрации назначается 25 июля. Проживающие в уезде обязаны зарегистрироваться при волостных и сельских ревкомах. Лица, кои будут обнаружены после указанного выше срока не зарегистрированными, будут рассматриваться как тайные агенты Панской Шляхты и привлечены к строгой ответственности» ${ }^{12}$.

После прекращения военных действий между Советской Россией и Польшей репрессии в отношении поляков были значительно ослаблены. В Енисейскую губернию поступило указание из Народного комиссариата юстиции от 29 октября 1920 г.: «В виду заключения прелиминарного договора между Россией и Польшей, предлагается на основании ст. 8 договора принять к руководству и немедленному исполнению следующее: 1 . Преследование судебное, административное, дисциплинарное и всякое иное против поляков гражданских пленных, интернированных и заложников, а равно беженцев, эмигрантов и военно-пленных - прекращается: по преступлениям и проступкам, совершенным до подписки прелиминарного договора, т. е. до 12 Октября сего года. 2. Приведение в исполнение наказаний... приостанавливается. 3. Лица... освобождаются из заключения, если орган и учреждения, за которыми они числятся, признают возможным...» ${ }^{13}$.

С подписанием 18 марта 1921 г. в Риге мирного договора все лица польской национальности получили право оптировать гражданство Польши. Ре-

11 Красноярский рабочий. 1920. 10 марта.

12 Государственный архив Красноярского края (ГАКК). Ф. Р-852. Оп. 1. Д. 1. Л. 143.

13 Архив города Минусинска. Ф. Р-34. Оп. 1. Д. 1. Л. 34. 
патриация проводилась в 1921-1924 гг., занималась ею Сибирская комиссия по эвакуации (Сибэвак). 27 мая в Новониколаевске открылось представительство Польши по делам оптации и репатриации. Историк Л. К. Островский пишет: «Первая группа польских военнопленных отправилась в Польшу из Красноярска 1-м эшелоном 14 августа 1921 г., она состояла из 1200 чел. 2-й эшелон прибыл в Москву 26 октября, в нем находилось 960 пленных с семьями, всего - 1253 чел., 3-й эшелон, в котором находилось 1176 чел., вышел из Красноярска 4-го октября, а 4-й - 6 октября... 5-й эшелон из Красноярска из 1158 военнопленных был загружен 31 октября, две недели стоял на станции...» (Островский 2014: 73).

Организовать возвращение поляков из Приенисейской Сибири на родину было не просто. Исследователи отмечают: «Организация реэвакуации осложнялась размещением военнопленных на обширной территории Сибири и худшими по сравнению с Европейской Россией коммуникациями. 25 октября 1921 г. уполномоченный К. Гинтовт информировал российско-украинскую делегацию о том, что в районах, прилегающих к Красноярску, проживают лица, имеющие право на репатриацию, но не располагающие необходимой информацией из-за плохой работы почтовой службы... и дезинформации» (Оплаканская 2015: 121). Осложнялся отъезд членов семьи, задействованных на службе в советских учреждениях. Например, в октябре 1921 г. было отказано в увольнении из амбулатории в д. Пировское Енисейской губернии жене военнопленного Г. Марыняк, которая должна была выехать в Красноярск для реэвакуации на родину вместе мужем Станиславом (Оплаканская 2015: 123)

Несмотря на массовую и организованную отправку во второй половине 1921 г. поляков из Красноярска на запад, на родину смогли выехать лишь половина польских легионеров. Исследователи пишут, что «Репатриация польских военнопленных завершилась в 1922 г.» (Оплаканская 2015: 125). На самом деле вопрос о возвращении легионеров и других поляков на родину оставался актуальным еще некоторое время, репатриация продолжалась и в 1923 г. В «объявлении Енисейского уисполкома» от 26 декабря 1922 г. говорилось: «Польским репатриантам, состоящим на учете эвакстола отдела управления, и военнопленным пятой польдивизии, отставшим от эшелонов по уважительным причинам... и желающим возвратиться на родину, предлагается не позднее 10 января 1923 г. подать мотивированное о том заявление с приложением документов о причине невыезда, как то: свидетельство врача о болезни, удостоверение сельсовета или волисполкома о поздно полученном извещении, заявление с просьбой о назначении на очередной отходящий эшелон. Не подавшие заявление к указанному сроку будут сняты с учета» (Минина 55). В «объявлении Енисейского уисполкома» от 26 декабря 1922 г. говорилось: «Всем иностранным контингентам: беженцам Польши и Литвы, не получившим визы иностранного представительства (т. е. вычеркнутых из эшелонных 
списков за недостаточностью документов), сообщается, что последние могут быть включены в эшелонные списки только по представлении в эвакстол отдела управления справки иностранного представительства... и справки особоуполномоченного в Сибири... не позднее 31 декабря 1922 г. Не представившие с сроку требуемых справок будут сняты с учета» (Минина 56).

Многие проблемы поляков были связаны не со злым умыслом идейных лидеров, а вызывались плохой работой советского чиновничьего аппарата. В «приказе по отделу управления Енисейского губисполкома» от 28 июля 1923 г. говорилось: «Ачинский УОУ (уездный отдел управления) крайне вяло провел работу по репатриации, результатом чего явилась далеко не полная отправка репатриантов по Ачинскому уезду. Несмотря на телеграфное распоряжение ГОУ, списки на репатриантов не были полностью и своевременно представлены в ГОУ для наложения визы польской делегации. Репатрианты... оказались в момент прихода эшелона размещенными по частным квартирам... та небольшая часть репатриантов, которые случайно оказались станции, была погружена наспех и в большей своей части не снабжена никакими беженскими документами... эти репатрианты, прибывшие на станцию Н-Николаевск, были почти целиком высажены русско-украинской делегацией и отправлены обратно за получением документов» (Минина 67). Здесь же отмечалось, что работа по данному вопросу вполне удовлетворительно проведена была только в Канском уезде.

В Польшу из Сибири уезжали не только военнопленные и ссыльные, но российские поляки. Например, в 1922 г. из Красноярска уехала в Польшу дочь умершего в 1919 г. дворянина, полковника русской армии Модеста Мольчевского. Репатриация на родину далеко не всегда вызывалась антисоветскими настроениями. В Польшу уезжали и вполне лояльно настроенные к СССР и русским поляки. Например, в 1923 г. на родину вместе с русской семьей поехал Ян Лукич Проминский, который во время ссылки в Шушенском познакомился с В. И. Лениным и пользовался поддержкой советского лидера после победы Советской власти в Сибири, а его старший сын Леопольд работал в ЧК и милиции в Забайкалье (Кикилова. С. 91-95). Во время и в результате репатриации оказались разделенными многие польские семьи. Абаканский исследователь В. Н. Тугужекова приводит пример: «В 1919 г. Витольд Гурницкий организовал под Минусинском артель «Товарищество каменотесов»... Его отец Доминник Гурницкий в 1921 г. был репатриирован в Польшу, а Витольд остался в Сибири. У него в это время было уже семеро детей...» (Тугужекова 66).

Не все поляки, получившие возможность вернуться на родину, покинули Сибирь. В семейных воспоминаниях иногда просто отмечается: «Через 30 лет ссылки Станислав Войда получил разрешение выехать в Польшу на постоянное или временное жительство... Но поездка не состоялась» (Войда. С. 108). По- 
павший в плен у станции Клюквенной И. В. Кулита в 1920 г. вступил в РКП(б), работал на Черногорских угольных копях и не стал репатриироваться «потому, что, симпатизировал Советской власти» (Оплаканская 2014: 99). Были примеры возвращения уехавших в Польшу обратно в Сибирь, например, семья умершего по дороге домой Я. Л. Проминского потом вернулась из Польши на родину. Во время возращения поляков на родину в первой половине 1920-х гг. выезжали лишь католики, но не поляки-мазуры, которых часто смешивали или путали с немцами.

Одновременно с репатриацией в Центральной Сибири шел процесс принятия поляками советского гражданства. В конце 1921 г. по результатам поездки в Канск инструктор польской секции докладывал: «зарегистрировано к отправке на родину беженцев 536 семей - 2340 душ. 15 семей эмигрантов, 25 военных. Подданство России приняли 38 семей - 160 душ» (Улейская 72). В июле-сентябре 1924 г. в Енисейской губернии приняли гражданство СССР 87 поляков. Цифра эта хоть и не большая, но все же поляков здесь больше, чем представителей других национальностей (Минина 79).

Ряд исследователей утверждают, что в первые годы советской власти численность поляков в Центральной Сибири резко сократилась. Красноярский историк Т. А. Улейская пишет, что в 1921 г. разные переписи давали общую численность поляков в Енисейской губернии от 11,8 до 20 тыс. чел., а в 1924 г. здесь было зафиксировано 4593 чел. польского населения (Улейская 72-73). Однако опубликованные документы указывают на иную картину. В «списке нацмен населения Енисейской губернии» за 1924 г. указано 12825 поляков (Минина 94). По данным на 1 января 1925 г. в Енисейской губернии было 11825 поляков. В этом году в Красноярском уезде насчитывали 6746 поляков, в Минусинском - 1364, в Канском - 2050, в Ачинском - 1439 (Минина 110). В 1926 г., согласно документам, в регионе насчитывалось 14679 чел. польского населения (Минина 128).

Таким образом, первые послереволюционные годы были важным периодом в истории поляков в Приенисейском крае. В 1920-1921 гг. Красноярск стал местом концентрации значительной части поляков в Сибири, одним из центров политических проблем и противоречий, связанных с польской миграцией. Противоречивое положение поляков в Енисейской губернии, как на всей территории России, в первые послереволюционные годы было обусловлено как противоречивостью эпохи, так и неоднородностью польской общины.

\section{БИБЛИОГРАФИЯ}

Bykonya G. F. i dr., cost. Mezh'etnicheskiye svyazi Priyeniseyskogoregiona 1609-1916 gg. Sbornik dokumentov. Ch. I. Krasnoyarsk, 2007. 
Vis'nevskij Ya. „Vojsko Pol'skoye v Sibiri vo vremya revolyutsii i grazhdanskoy vojny v Rossii” Revolyutsionnaya Rossiya 1917 goda i pol'skij vopros: Novyye istochniki, novyye vzglyady. Sbornik statej pol'skikh i rossijskikh issledovateley. M.: Institut slavyanovedeniya RAN, 2009.

Vojda Yu. M. „V sibirskoj dal'nej storone...” Istoriya i kul'tura polyakov Sibiri: Sb. materialov mezhregion. nauch.-prakt. konf. «Istoriya i kul tura polyakov Sibiri» 2005-2006 gg. / sost. i podg. k izd. S. V. Leonchik. Krasnoyarsk, 2006.

Drozdov N. I., gl. red., Yeniseyskiy' entsiklopedicheskiy slovar'. Krasnoyarsk: KOO Assotsiatsiya «Russkaya entsiklopediya», 1998.

Kikilova T. M. „Stranicy zhizni pol'skoj sem'i (na osnove nauchny'h materialov muzeya-zapovednika «Shushenskoe»)" Istoriya i kul'tura polyakov Sibiri: Sb. materialov mezhregion. nauch.-prakt. konf. «Istoriya i kul'tura polyakov Sibiri» 2005-2006 gg. / sost. i podg. kizd. S. V. Leonchik. Krasnoyarsk, 2006.

Minina S. A. i dr. cost. Mezh'etnicheskiye svyazi Priyeniseyskogoregiona 1917-1992 gg. Sbornik dokumentov. Ch. II. Krasnoyarsk, 2007.

Nam I. V. „Pol'skie organizacii i sibirskaya oblastnaya duma (1917-1918) gg.” Chelovek - tekst - e'poha: Sb. nauch. statej i materialov / Pod. Red. V. P. Zinov'ev, O. N. Bahtina, E. E. Dutchak. Tomsk: Izd-vo Tom. un-ta, 2008.

Oplakanskaya R. V. „Plenny'e polyaki - uchastniki «belogo dvizheniya» na yuge Sibiri v nachale 1920h gg." Polyaki v Sibiri: ot povstancev 1863 g. do sovremennoj polonii: Kollektivnaya nauchnaya monografiya pod redakciej Sergeya Leonchika. Krasnoyarsk, 2014.

Oplakanskaya R. V. „Deyatel'nost' predstavitel'stva smeshannoj komissii v Sibiri po repatriacii pol'skih voennoplenny'h v 1921 godu”. Tomsk Journal LING \& ANTHRO. 3 (2015).

Ostrovskij L. K. „Pol'skie voenny'e v Sibiri (1904-1920 gg.)” Vestnik Tomskogo Gosudarstvennogo Universiteta. 316 (2008).

Ostrovskij L. K. „Repatriaciya optantov, bezhencev i voennoplenny'h iz Sibiri v Pol'shu (1921-1924)” Gumanitarny nauki v Sibiri. 3 (2014).

Otchet Yeniseyskogo Gubernskogo Ekonomicheskogo Soveshchaniya Sovetu Truda i Oborony i Sibirskomu Oblastnom Oblastnomu Ekonomicheskomu Soveshchaniyu s 1-go Oktyabrya 1921g. po 1-ye Maya 1922 g. Krasnoyarsk: Gosudarstvennaya tipografiya, 1922.

Tuguzhekova V. N. „Gurniczkie-Ky'zlasovy' - v istorii Hakasii” Polyaki v Sibiri: ot povstancev $1863 \mathrm{~g}$. do sovremennoj polonii: Kollektivnaya nauchnaya monografiya pod redakciej Sergeya Leonchika. Krasnoyarsk, 2014.

Ulejskaya T. A. „O pol`skoj sekcii Gubnacz v 20-e gody` XX veka”Istoriya i kul’tura polyakov Sibiri: Sb. Materialov mezhregion. nauch.-prakt. konf. «Istoriya i kul tura polyakov Sibiri» 2005-2006 gg. / sost. i podg. k izd. S. V. Leonchik. Krasnoyarsk, 2006.

Sheksheev A. P. „Inostranny'e voennoplenny'e - svideteli i souchastniki revolyucii i grazhdanskoj vojny' v Rossii (na materialah prienisejskogo regiona)" Gumanitarny'e problemy' voennogo dela. 1 (2017).

Shostakovich B. S. „Proshloe i nastoyashhee Irkutskoj Polonii. Obshhaya harakteristika temy' i aktual'ny'e problemy' ee izucheniya" Diaspory' v istoricheskom vremeni i prostranstve. Nacional'naya situaciya $v$ Vostochnoj Sibiri /Tez. dokl. Mezhd. nauch.-praktich. konf. Irkutsk: Irkutskij gosudarstvenny'j universitet, 1994. 
